\title{
Pakistan and the FATF: Exploring the Role of Diplomacy in Getting off the Grey List
}

\author{
Muhammad Idrees $^{1}$, Manzoor Ahmad Naazer*1 \& Hashmat Ullah Khan ${ }^{2}$
}

1. Department of Politics \& International Relations, International Islamic University, Islamabad, Pakistan.

2. School of International and Public Affairs, Jilin University, Changchun, Jilin, China.

\begin{abstract}
Pakistan has been on the 'Grey List' of the Financial Action Task Force (FATF) - the international money laundering and terror-financing watchdog. Pakistan's engagement with the task force is not new, the country faced FATF indictments during 2008 and 2012 to 2015. Despite Pakistan's efforts to curb AML for CFT and huge diplomatic commitments, the task force retained Pakistan on the 'Grey List' on account of its Risk Profile. Though other countries get clearance after fulfilling 80 percent compliance, but Pakistan has been pressurized for a hundred percent compliance with the action plan. There are severe drawbacks for being remained in the grey list for banking system, export and imports, remittances, international lending and foreign investments but the most severe would be its dropping into blacklist. The September 2020 Legislation would help gathering diplomatic support in the forthcoming settings. The supportive role-played so for by China, Turkey, Malaysia at the task force has worked in averting Pakistan from blacklisting. Therefore, the study suggests that powerful diplomacy can break the FATF clutches and get Pakistan out of the 'strategic deficiencies list' or grey list. Explorative, historical and analytical conclusions have been brought in content analysis format.
\end{abstract}

Keywords: FATF, Blacklist, Grey List, White List, Strategic Deficiency, Diplomacy, Modern Diplomacy, Financial Bearing.

\section{Introduction}

Pakistan has once again made it possible to avoid blacklisting by the Paris based financial watchdog-FATF, but it would be retained on the 'Grey List' for its failure to fully comply the task force action-plan's targets aimed at AML and CFT. If a country fails to meet the parameters laid by the task force it is called a violation by FATF: "under the category of antimoney laundering and countering the financing of terrorism - known as AML and CFT violation" (Basu, 2020). The current government of PTI headed by Imran Khan though had taken some steps to ease the concerns of the international community e.g., the detention of Hafiz Saeed (head of Lashkar-e-Taiba a banned organization) the alleged mastermind of Mumbai attacks-2008, arrest of his top officials on account of FT (Aljazeera, 2019). News sources revealed that the step was appraised by the US State Department head Alice Wells: "Pakistan for its own future must prevent militant groups from operating on its soil" - but "India, still, is not satisfied with Pakistan's efforts and demanding FATF to blacklist the country" (DW, 2019, October 18). The Indian efforts of pushing Pakistan into the blacklist were aimed at bankrupting her (Saeed, 2019). 
FATF is used as a modern instrument by powerful countries of the west against the weaker ones to make them comply with their commands. Pakistan's-Kashmir diplomacy so far has been meaningless in the powerful western capitals. In 2017, Pakistan sent its top diplomats to Washington, Paris and Brussels to expose Indian atrocities in held Kashmir, but they did not give heed, and demanded Pakistan to act against Hafiz Saeed. Ajmad Shoaib, a leading defence analyst expressed that "India and U.S have ganged up against Pakistan, but we should not be blackmailed, though there was no evidence against Hafiz Saeed still we arrested him" (DW, 2019, July 17). All these instances highlight the importance of compliance with demands of powerful western elites. Another dimension of the Pakistan-FATF engagement according to analysts is pressurizing Pakistan to bring Taliban towards peace settlements. "The blacklist threat is used to force Pakistan to serve American interests," told Shoaib. But according to others, it is not all correct to distinguish between good and bad militants - we must take concrete actions against militant organizations. To Kakar a Pakistani senator, "Pakistan is not going to be blacklisted by the task force, it will give us more time because Washington needs Islamabad right now" (DW, 2019, October 18).

Pakistan needs to launch an aggressive diplomacy to secure an enough support to get off the grey list and prevent itself from falling into FATF-blacklist. The diplomatic support would strengthen Pakistan's position at the body and make ways for Pakistan to come out of its clutches. In such a situation the support of friendly countries e.g., China, Turkey, Saudi Arabia and Malaysia would add to the position of Pakistan. But this would not be enough to get off the grey list, as there is dire need of much more than desired: Pakistan needs to satisfy the Western elite about its AML and CFT efforts. The research is mainly focusing upon how Pakistan can create space for its exit from the watchdog. What are the main hurdles in its way to get a clean chit from the watchdog? How can legislation and diplomacy make a change? Taking in view all these queries the study focuses on role of strong diplomacy to get off the grey list and avoid blacklisting at FAFT. Further, the legislation and practical steps taken by government and its agencies to meet the standards has been discussed. But the watchdog does not look satisfied with Pakistan's efforts and there is dire need of 'do more' for curbing AML and CFT regimes.

\section{Literature Review}

IOs have tempered the dictum handed down to prosperity by Thucydides that, the strong do what they can and the weak suffer what they must. The multilateral diplomacy implied by UN differs from the traditional Interstate Diplomacy in many respects. These too add to the institutional congestion and complexity of modern diplomacy (Cooper et al., 2013). The stronger members of UN and EU are also members and originators of subsequent financial organizations and FATF. For achieving compliance with standards set by their patterned organizations they use embargos and or even more sophisticated economic sanctions in the pursuit of national security and foreign policy objectives. The modern tools of diplomacy include selective and comprehensive imposition of trade and financial sanctions. These tools have become 'Go To' option for today's decision makers. The growing foreign policy and national security threats emanating from state and non-state actors has been turning into strategic liability (Karn \& Mingst, 2013; McGlinchey, 2017).

The operating of diplomacy is the pre-requisite of strengthening bilateralism and acquiring support base at international forums where decisions are based on voting strengths. The tool of economic sanctions has been in constant use after World War II, which woes for side-lining 
the conventional techniques and operating of the diplomacy in day-to-day international relations. Modern diplomacy is the "use of Theodore Roosevelt's big stick" and that seems to be a routing of the $21^{\text {st }}$ century (Stanzel, 2018). Pakistan has both diplomatic weaknesses and strengths at the FATF. Pakistan's strengths are the friendly countries support at the forum; and, US needs in Afghanistan peace process in which Pakistan has been playing a prominent role. However, some serious nature weaknesses are Pakistan's internal terrorist landscape and the Indian lobby at the penal.

Pakistan's challenges at FAFT are exacerbating due to politicization of the decision-making process at the body. Amid, the Indian move for attaining a co-chair of the Asia Pacific Joint Group would have severe consequences for Pakistan. In 2018, when the FAFT put Pakistan on its grey list, the country was undergoing a political transition. It was facing economic crises due to lowering economic growth, debt problems and fiscal imbalances. The efforts made by the country in the face of accusations by the task force are cumulative to keep off blacklisting. To make it possible, and/or to get off the 'grey list' Pakistan required the backing of 15 out of 37 member's jurisdictions. Pakistan needs a strong diplomatic engagement with FATF and its member states in the coming months: "presenting evidence of Pakistan's clearance of FAFT's items list and highlighting the importance of de-politicization in FAFT decision making process" (Noor, 2019).

To counter money laundering and terrorism, the Security and Exchange Commission of Pakistan (SECP) is trying at its best effort; the efforts so far include the Memorandum of Understanding (MoU) with NACTA for enhancing coordination levels for combating and creating awareness among the public and financial institutions about AML and CFT as per dictation by the FAFT (Amin et al., 2020). Mukhtar (2018) elaborates the role of FBR and Ministry of Finance for establishing a working group for the documentation of Pakistan economy. In this regard the government should invite private sector money exchangers who have knowledge of the channels through which illegal transactions are made-Pakistan should augment its diplomatic efforts and proactively deal with the FATF and observer organizations and countries (Mukhtar, 2018).

\section{Research Methodology}

The study design is based on qualitative analysis of the background and progress of the issue envisioning the future prospects. During the research all relevant data mostly available online from official websites of FATF and the associated institutions were contacted. The study mostly relied upon research papers published on the subject matter and newspapers updates. After collecting the most relevant available information on the theme of study, the data was analysed and scrutinized before its systematic presentation in the content analysis format. The first part of the study is introductory, presenting the theme of study, while the second part presents the background understanding about FATF. The third portion discusses the objectivity and procedural matter of the forum. The subsequent parts discuss Pakistan's engagement with the forum during different quarters of the decade and focus the current engagement. Next, the role of diplomacy in avoiding blacklisting has been fully elaborated to explain the diplomacy has worked for Pakistan so for. At the end, great stress has been put on Pakistan's sincere efforts e.g., AML and CFT related legislation and practical steps taken to meet the FATF standards but beyond all such efforts this portion concludes stressing the importance aggressive and meaningful diplomacy to get off the grey list. 


\section{Discussion and Findings}

\subsection{Organization, Structure and Functioning of FATF}

FATF the world level forum on money laundering and terror financing has set international standards to prevent these illegal activities and secure society from such menace. In the policy domain it works for gathering political will and brining national level legislative and regulatory reforms in these areas. According to the available data, about 200 countries follow its jurisdictions and committed to implement them. The FATF-Recommendations also called FATF-Standards ensure a coordinated response to halt ways to corruption and terrorism. The standards help authorities in chasing criminals dealing in illegal money, drugs and human trafficking. The watchdog also works for stopping funding for weapons of mass destruction. It makes the countries bound to follow FATF standards and held accountable otherwise.

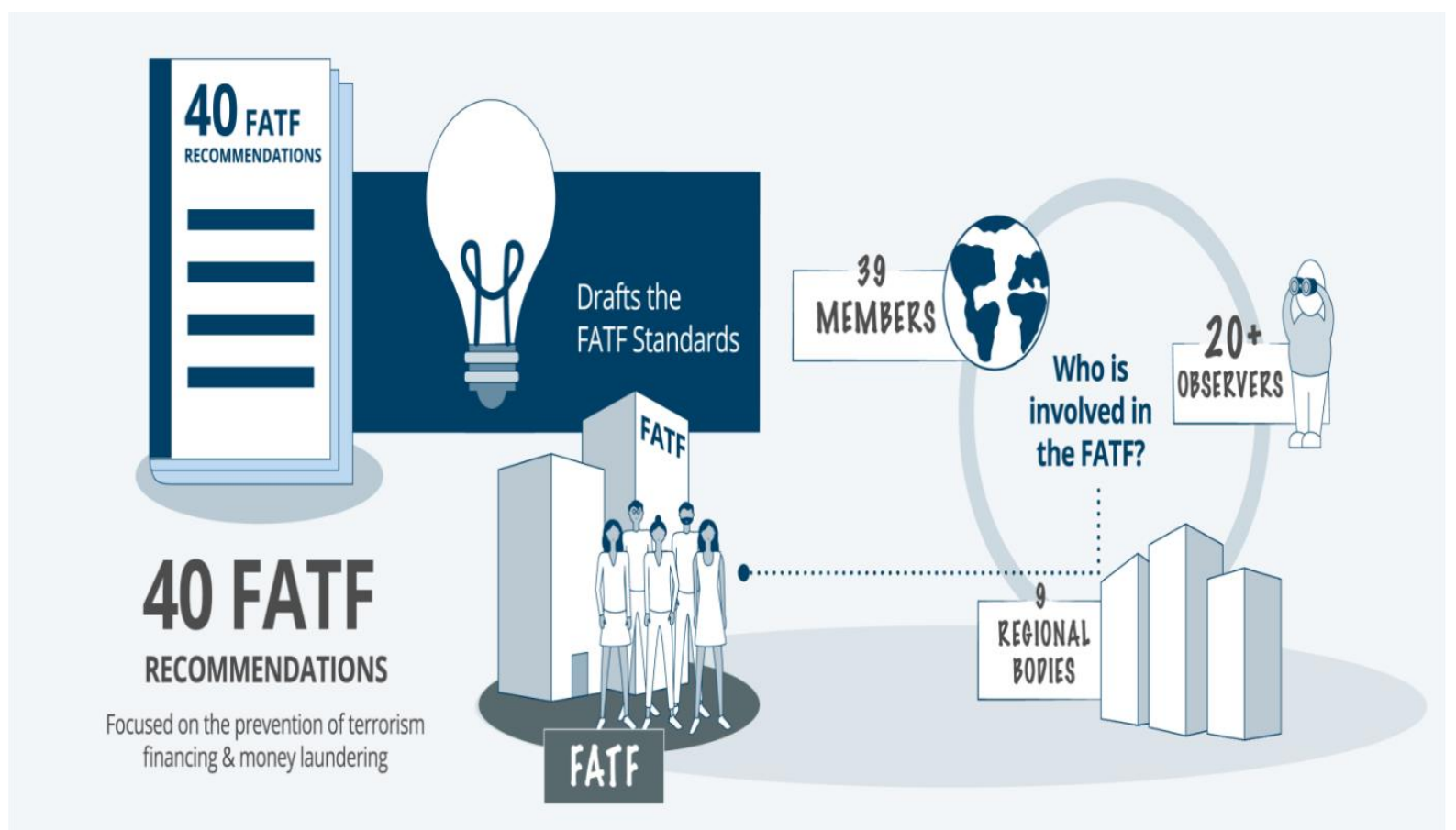

Figure 1: The FATF Organization \& Structure. https://fatfplatform.org

The FATF presently consists of 39 members including two regional organizations e.g., the Gulf Cooperation Council and the European Commission. Its additional associate members who number is nine (09), work for implanting its mandate on a regional basis. Almost twenty world bodies have observer status at the forum; the most prominent are World Bank, IMF, OECD and various UN bodies.

\subsection{FATF Objectivity - 'Blacklist' and 'Grey-list'}

\subsubsection{Mutual Evaluation Process}

The governments are assigned with the task of enacting laws and adapting rules and regulations according to its recommendations. The Manual Evaluation (ME) process facilitates the countries to make periodical evaluations of each other's' progress in regard to implementation 
of the standards. The evaluation is meant to check compliance while poor evaluation must have negative impacts and bearings for a country's trade, investments and debt prospects.

FATF is a policy making body which is working to generate political understanding about national level legislation and regulatory reforms. The body has developed its own recommendation mechanism called 'FATF Standards' aimed at coordinating global-level response building to prevent: "organized crime, corruption and terrorism." These standards help governments to go after the criminals involved in illegal drugs business, human trafficking and other crimes of the kind. It also works against financing or funding for weapons of mass destruction (WMD).

The FATF is an independent inter-governmental body that develops and promotes policies to protect the global financial system so that it could not be used by the terrorists and other anti-social elements (Singh, 2020).

The body works continuously on strengthening its standards to address new risks. For this purpose it reviews the money laundering and terror-financing techniques: such as the regularization of virtual assets, which have spread as crypto currencies gain popularity (FATF, n.d.). The watchdog has a monitoring mechanism for countries under observation. It checks the compliance with its standards by countries while non-compliance would hold countries accountable. Though the body has developed a standardized set of rules with global appraise and promoted controlling measures over the time yet amid all these benchmarks the body has been criticized on its selective use of the FATF-guidelines. "In the case of Pakistan, the FATF is alleged to have allowed political elements to permeate its processing" (Noor, 2019).

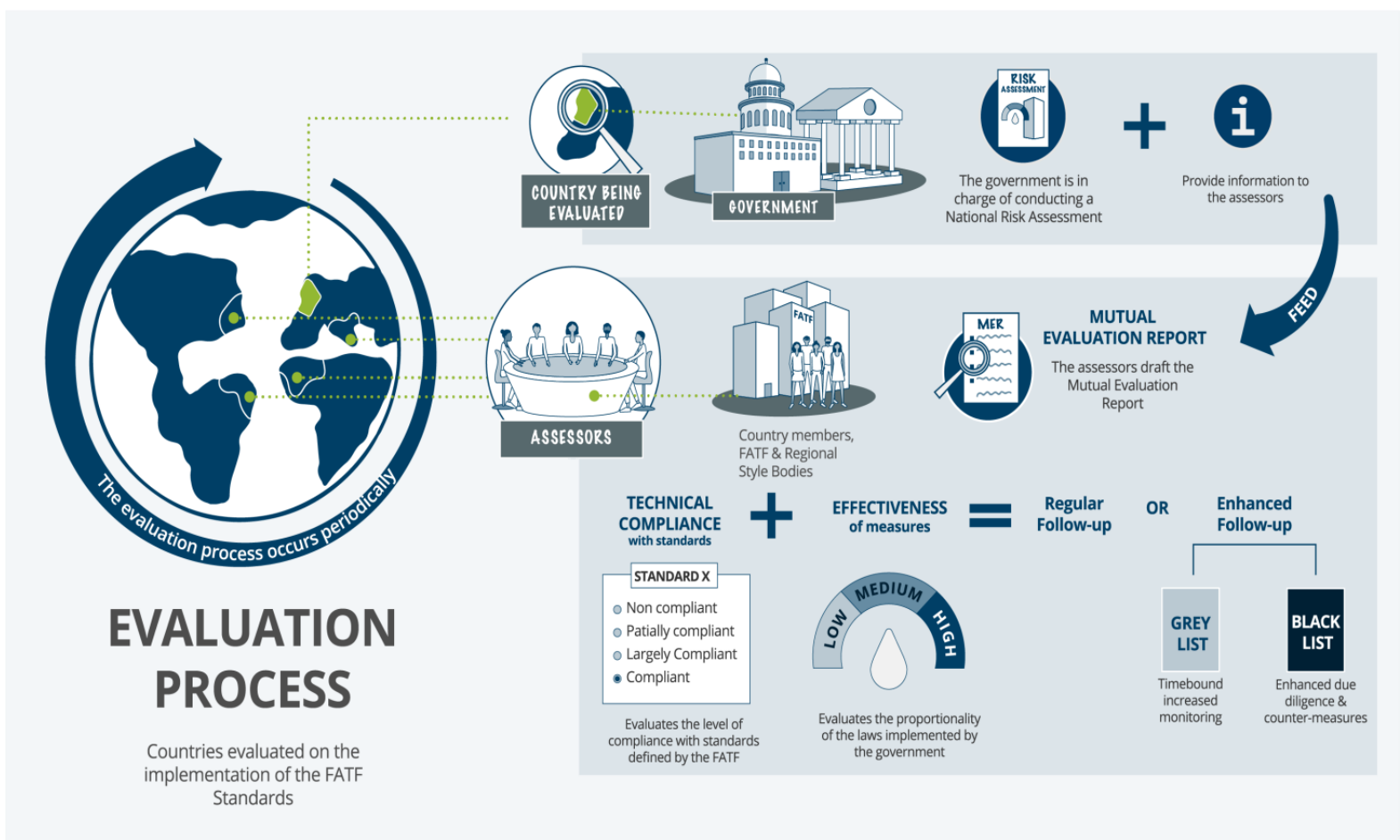

Figure 2: Evaluation Process at the FATF. https://fatfplatform.org/

The FATF selective harassment is raising questions about its objectivity. There are charges that 
FAFT has deviated its original path and that it has been selectively targeting few countries while totally ignoring others having similar or worse criminal records. "Some international money laundering hubs such as Cayman Islands are still outside the watchdog's stringent restrictions despite having received negative reviews by the body" (Noor, 2019). Threat profile of a country greatly influence FATF recommendations, they are subject to be more partial. There is peer review assessment of countries technical compliance against a uniform checklist containing the country's fulfilment or non-fulfilment of FAFT standards. The assessment contains technical compliance and effectiveness, which may vary by country.

\section{The Processes of Money Laundering and Financing of Terrorism}

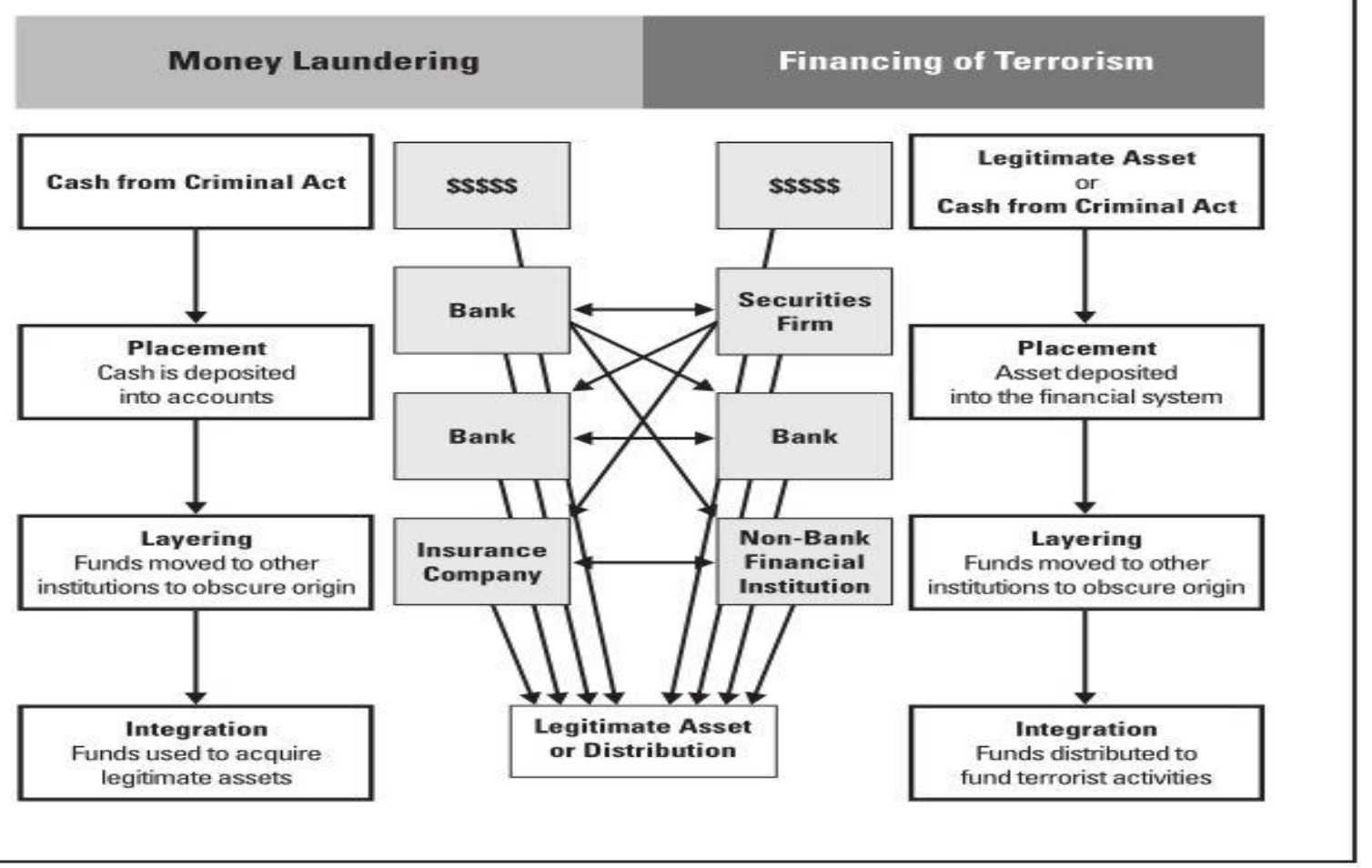

Figure 3: Similarity: The Process of Money Laundering \& Financing of Terrorism. foreignpolicynews.org/wp-content/uploads/2016/10/Process-of-money-laundering.jpeg

\subsubsection{Black List and Grey List}

Black List and Grey List, the most often attributed explanations to FATF charge sheets. Officially known as High-Risk Jurisdictions, 'Subject to a Call for Action', the FATF-Blacklist sometimes referred to as 'OECD-Blacklist' is a list of countries that are viewed as noncooperative and deficient in implementing the global agenda of AML and CFT. It is very much likely that the blacklisted countries would face economic sanctions and prohibitive measures by the organization's member states and other international organizations.

The body works on strict lines with implementation mechanism by its members. The FATF 'public statement' is a document that identifies two categories of countries. The first category is the set of countries having imbalanced charge sheet with serious strategic deficiencies what may called as roughly equivalent to blacklist. Against such deficient countries or more understandably the so called 'blacklist' the members and non-members are called by FATF to apply counter strategies (The Wire, 2020). 
A second category consists of applying diligence measures by FATF member countries proportionate to the risk-factors of the suspected country. North Korea lies in the first while Iran rests in the second categories respectively. Pakistan though was not identified in the public statement but appeared in the second document that was issued after plenary meeting in June 2018. This second document was called "Improving Global AML/CFT Compliance: OnGoing Process". The second document in view is colloquially called the Strategic deficiency or 'grey list'. Countries at this stage pledge commitments for the full-pledged implementation and coordination of FATF action plan. In the wake of a country's inefficiency in fulfilling FATF tighten the rope and put further pressure upon it by moving it to 'Public Statement' (Khan, 2020).

\subsection{How Pakistan Came in the Grey-list?}

Pakistan came under FATF monitoring under 'strategic deficiency' first in 2008, then from 2012 to 2015 respectively. But it managed to avoid further monitoring by making significant achievements in the areas of anti-money laundering and international terror financing (AML \& CFT). The statement issued by FATF in 2012 dignified Pakistan's working and its capacity building of financial intelligence units, placing the UNCE-enforcement order and developing AML and CFT guidelines for exchange companies - and currency declaration notification for implementing cash border controls (Noor, 2019).

Pakistan's current status at FATF 'Grey List' came in June 2018 at the behest of USA and UK backed by France and Germany (Wolf, 2019). The initiative came just after the American president's statement 'to take tough measures against Pakistan', blaming Pakistan for providing safe havens to terrorists. Under the present regimes, Pakistan has to comply with the Action Plan monitored by International Cooperation Review Group and improvises its AML and CFT in close observance by Asia Pacific Group (Karim \& Hayat, 2019).

Pakistan has so for managed to avoid blacklisting by expressing its political commitment to complement the Action Plan and achieving progress in different domains. The achievements include updating AML and CFT frameworks, establishing inter-agency mechanism for coordination and compilation of suspicious transaction reports. These initiatives were followed by estimated some 700 FT-investigations and mapping almost 64,000 non-profit organizations. The Action Plan for Pakistan constituted 27; items Pakistan has addressed 5 completely, 17 partially while 5 remain incomplete (Noor, 2019). Despite incompetency in some areas significant progress was made by Pakistan from January 2019 onwards. Pakistan's active involvement on diplomatic front to gain maximum support at the FATF plenary and avoid blacklisting proved well. Pakistan's friendly countries e.g., China, Turkey and Malaysia voted in favour of Pakistan which made Pakistan to avoid blacklisting. Pakistan needs more diplomatic support to get off the grey list.

FATF in its October meeting did not appraise Pakistan's efforts and raised serious concerns about the lack of progress to CFT. The task force unveiled that by adapting to five out of 27 items Pakistan has only avoided blacklisting. The US authorities want Pakistan to do more and take "consistent and irreversible" steps against terrorists and militants to sustain and improve its relations with United States (Syed, 2019). In line with these commitments the United States suspended military aid to Pakistan in order to force her to work for eliminating militants hide outs on its soil. The research of brooking institute reveals that during 2010 to 2018 the U.S 
military aid to Pakistan has been decreased by 60 percent without having a significant impact on Pakistan's behaviour (Felbab-Brown, 2018).

Michael Kugelman (an expert) of the Woodrow Wilson International Centre, Washington was of the view that, "the US was not happy with mere arrest of militants, she wants more than that e.g., arrest of their leaders, putting them on trial and ceasing the militant infrastructure" (George \& Hussain, 2020). According to Schwemlein of the Carnegie Endowment for International Peace, the FATF mandate is simply to fix and verify regulatory shifts and legal changes not to dismantle complex terrorist networks. The escape of Ehsanullah Ehsan Washington post writers George and Hussain (2020) mentioned the master mind of Malala Yousafzai (the famous education activist) assassination attempt, "This was such a high-profile case, if [Ehsan] can escape without any hurdle, just imagine what it's like for someone with a lower profile."

\subsection{The Role of Diplomacy so for in Avoiding Blacklisting}

The main agenda for Pakistan by FATF is to clear its terrorist landscape and stop nurturing terrorists. Pakistan is fearful of losing patronage and support of the friendliest nations e.g., Saudi Arabia and China if do not comply with FATF-Action Plan (Wolf, 2019). There is also great probability to put Pakistan in the blacklist if does not fulfil the commitments within due frame of time. The initiatives taken by Islamabad till now to avoid blacklisting includes the seizure of JuD assets and putting its entire leadership on trial including Hafiz Saeed, the alleged mastermind of Mumbai-2008 attacks (DW News, 2019, July 17).

Ayesha Sidiqa, analyst and researcher expressed that Pakistan had been unlikely to close her proxies soon; she would be believing it when JeM infrastructure is downsized and its leader Masood Azhar is publicly arrested and put on trial - "with Afghanistan still brewing, I don't think we are close to cleaning our house". However, the Wilson Centre's Kugelman thinks differently, he appreciates Pakistan's steps taken against CFT and militant groups, but he is suspicious that there will be concerns within FATF until Islamabad takes conclusive steps (Shahzad, 2019). For averting blacklisting a country needs the support of three voters which Pakistan secured by the support of friendly countries China, Turkey and Malaysia but the archrival India is trying her best to push Pakistan towards blacklist. Iran and North Korea are the countries currently on the FATF blacklist which hinders the countries' international borrowing capabilities and puts the economies under pressure. Iran and North Korea, due to blacklist are severely restricted from international borrowing.

If the FATF blacklists Pakistan, it may lead to downgrading of the country by multilateral lenders like IMF, World Bank, ADB, EU and also a reduction in risk rating by Moodys, S\&P and Fitch (The Economic Times, 2019).

Pakistan is trying hard to manage getting off the grey list, its recent decisions about Afghan Taliban. Pakistan has issued financial sanctions against the group amid of the US engineered Afghan Peace Process. Pakistan is playing a vital role in the process by engaging the stakeholders and mediating with the Afghan government and the Afghan Taliban (Idrees et al., 2019). But the decision of sanction was motivated by the hard liners provided by the Paris based watchdog. The list included Taliban chief peace negotiator Mulla Baradar and Sirajuddin Haqqani and other prominent members of both the groups. The list of sanctioned terrorist groups, included beside Taliban, other terrorist groups also, the initiative was taken in 
compliance with UN resolution sanctioning Afghan groups and freezing their assets (TRTNews, 2020).

Pakistan's efforts aimed at Terrorism-Combating and breaking their financial networks speak about Islamabad's seriousness to comply with the requirements set by the task force. More recently, Pakistan's Prime Minister Imran Khan criticized India for working against Pakistan at FATF and charged that his nation has dismantled militant groups operating on its soil (Mohammad, 2019). India is the number one enemy of Pakistan which spare no efforts to defame Pakistan and make it vulnerable in efforts to emancipate the Indian occupied Kashmir (Idrees \& Ayaz, 2015). But James Schwemlein (expert on South Asia) of the Carnegie Endowment for International Peace views that, "Pakistan has taken only modest steps" he blames, "Pakistan's intelligence agency continues to maintain ties with militant groups" (Muhammad, 2019). But the Pakistani PM in view of all these types of statements urges the importance to eliminate all such militant proxies.

\subsection{Role of Diplomacy in Easing Indictments \& Making Ways out of The Grey-list}

Pakistan managed to avoid blacklisting amid rumours. The role of diplomacy in this regard was important, and Pakistan's escape from the blacklist is the fruit of friendly countries' support at the task force. The prominent Indian daily reported that Pakistan escaped because China, United States, United Kingdom, Australia, New Zealand, Japan, among others, did not make any adverse remark on Pakistan's action plan - and that United States needed Pakistan's support in the Afghan peace process (Tripathi \& Chaudhury, 2020). "Pakistan may have suffered diplomatic hiccups in the past but this time it seems the country is on the right trackexhausting the conspiracy faculties of the adversaries and setting its own house in order" (Saeed, 2019). News reports tells that there are 14 or 15 such countries having poorer AML and CFT arrangements than Pakistan, but they are out of FATF surveillance under grey list or blacklist (Dawn, 2020; Smuel, 2018).

There are much bigger diplomatic challenges for Pakistan in handling the affairs at FATF. The recent US pushing of Riyadh to cease her support for Pakistan and in return getting a full pledged membership at the forum. Pakistan's failure to maximize diplomatic support at the forum could be a going down the pothole - thus the aggressive diplomacy is required to avoid blacklisting the make a way out of grey list (Saeed, 2019). The Indian media's reports reveal that major powers like US, UK Japan, Australia, China and New Zealand did not make any adverse remark about Pakistan's performance which was seen as an indicated as Pakistan's strong case at FATF (Dawn, 2020).

Pakistan's parliament passed three bills related to FATF during a joint setting (Ahmad, 2020). The legislation is said to be helpful in preventing the country from being blacklisted by the financial action watchdog. The bills, believed by experts will also have salutary effects on the economy and revamping national image globally. Pakistan is struggling to get some ease at the FATF, avoid blacklisting and making ways to get out the grey list. The bills passed by the parliament aimed at Anti-Money laundering and CF-Terrorism, should serve as a testament to Pakistan's resolve in its fight against FT and AML (Xinhua, 2020). The Anti-Terrorism (third amendment) Bill-2020 is "essential to address the issue of terror financing, one of the major obstacles which is not only playing a degrading role against the development of the country 
but also imbuing such elements with the financial means which are an ultimate threat to the internal and external peace of the country" (Ali, 2020).

Nonetheless, the legislation would show a positive posture of the country, creating possibilities of making ways for getting off the surveillance of the global watchdog. According to analysts, Pakistan needs to launch an aggressive diplomatic effort to secure enough support at the plenary setting, to come out of the grey list and prevent itself from falling into the blacklist. At this stage, Pakistan would need 15-16 votes to move out the grey list and a minimum three votes to avoid blacklisting. The FATF penal currently comprises 36 members with voting powers and two regional organizations which represent the major financial centres throughout the world.

Pakistan's position would be further strengthened by the September legislation, which was precondition by the plenary discussion and would be considered a positive move by the strong members of the watchdog. Thus, controlling money launder and terror financing regimes could help amid diplomatic support by the friendly countries at the forum. Pakistan's efficacy has been understood in line with her efforts and role in the war on terror. Pakistan so far has been committed to dismantle terrorist sanctuaries from its tribal and frontier regions with Afghanistan. It has also taken possible administrative and legal measures to check and block the sources of funding to the terrorist organizations (Ashraf, 2020).

Pakistan has been working hard to eliminate terrorism from its soil and she proved to be the sincere partner and trusted U.S ally in the WOT. Pakistan's army has shown great progress and provided lessons for other countries under conflicts how to fight terrorism in a systematic manner. The operations in Swat, FATA and Waziristan regions are glaring examples of Pakistan's resolve to eliminate terrorist infrastructure. But till now the FATF decisions are reflective of the U.S rhetoric of 'do more' and it is obvious that the international organizations are playing cards in the hands of powerful countries like U.S (Ashraf, 2020). By using the pressure tools these powerful countries make the countries come up with their choice decision making and legislation. Pakistan's efforts for more working diplomacy at the forum is keeping Indian design in an abeyance and maximizing efforts in favour of Pakistan. It is pertinent to point out that Pakistan has avoided being pushed into the Black List because of the persistent support of China, Turkey and Malaysia (Ashraf, 2020).

So, there is presence of strong diplomatic assistance at the forum on the disposal of Islamabad which would add to the credibility of Pakistan. The retaining at grey list is a serious matter and amid internal economic crises Pakistan could not afford any mistake at any stage; means to provide chance to others to undermine its case (Jamal, 2019). Though, up to some extent India had tried to build pressure upon Islamabad at the forum supported by U.S initially. Pakistan being mindful of Indian lobby and her designs would not give chance to Washington to push her head with opposition to isolate Pakistan (Jamal, 2019).

The FATF, in its October 2020 setting found that Pakistan has successfully complied with $21 / 27$ points, but the watch dog still is not very much satisfied with Pakistan's compliance and kept the country under further observance via 'grey list'. The plenary, however stressed the need for working on four areas e.g., address the strategic deficiencies:

a) That Law enforcement agencies (LEAs) are actively involved in stopping terror financing networks and identifying and eliminating them. 
b) Demonstrating that prosecutions against terror financing are helping in proportionate and dissuasive sanctions.

c) Targeting, stopping and eliminating all including 1267 and 1373 designated terrorists and their affiliates terror financing related movements and actions.

d) The federal and provincial authorities must extend their coordination on the subject criminal penalties enforcement against those criminals who violate terror financing sanctions (Hussain, 2020).

In spite of the above realities and shortcomings that Pakistan held, it would need 12 out of 39 members to get off the grey list which has not been made possible till this time. Besides, lobbying for getting off the grey list, Islamabad also has to take care of the U.S temper amid the change in the presidential office. Then finally, Pakistan and the lobbyists on her behalf could claim that it has fully accomplished the tasks and achieved the target fixed by the watchdog. According to The Diplomat (2020) report, Pakistan's apex court (the Supreme Court of Pakistan) has granted six months extended custody to the suspect-killer of American journalist Daniel Pearl, accepting the appeal for justice made by his parents, despite the suspect's acquittal by a lower court. Pakistan's high-level diplomacy in Afghanistan would not seem to make ways out for Pakistan to shut the grey list at times, analysts observe (Solaimankhail, 2020).

\section{Conclusion}

Pakistan has been under constant pressure both domestically and internationally since the outbreak of Afghan crises in the wake of 9/11 attacks and the subsequent U.S and NATO intervention in Afghanistan. Pakistan actively supported the allied war efforts aimed at eliminating terror networks from Afghanistan and teaching a lesson to Al-Qaeda the terrorist organization held responsible for the 9/11. However, as a reaction to Pakistan's support to the allied powers actions and geographical contiguity with war-torn Afghanistan Pakistan did not escape the wrath jihadists and sectarian groups. They inflicted great damage to Pakistan's infrastructure and economy by launching terrorist activities against the people and state of Pakistan. Up to a level, the U.S and other western countries admired Pakistan's counter terrorism efforts, but they did not look happy with Pakistan's efforts to stop AML and CFT. Pakistan has made great progress by enacting national level legislation in compliance with the standards set by FATF and banned and freezing the assists of hundreds of terrorists' networks. It has also arrested many high-profile leaders and initiated their trials under criminal procedures. The September 2020 legislation and the arrest of Hafiz Saeed are most glaring incites of the fulfilment of such commitments. Yet, the FATF still not looks satisfied and retain Pakistan on the Grey-list. Till this time, Pakistan has taken time and avoided blacklisting because of diplomatic support at the watchdog. However, this is not enough, Islamabad needs to maximize diplomatic support at the forum and get off the grey list by taking steps that are more aggressive. 


\section{References}

Ahmad, I. (2020, September 16). After Senate defeats, Pak govt passes all FATF-linked bills via joint session. Hindustan Times. https://www.hindustantimes.com/worldnews/after-senate-defeats-pak-govt-passes-fatf-linked-bills-via-joint-session/storyS9ep7yUFGKW17ZLzKOWM6M.html

Ali, S. (2020, September 17). Legislation passed to get out of FATF grey-list. The Nation. https://nation.com.pk/17-Sep-2020/legislation-passed-to-get-out-of-fatf-grey-list

Aljazeera News. (2019, October 17).Pakistan expects to avoid 'terrorism' financing blacklist. https://www.aljazeera.com/ajimpact/pakistan-expects-avoid-terrorism-financingblacklist-191017175755573.html

Amin, M., Khan, M., \& Naseer, R. (2020). Pakistan in the FATF grey-list: challenges, remedies and international response. Margalla Papers (1), 31-43. https://ndu.edu.pk/margallapapers/Margalla-Papers-2020/03-Pakistan-in-the-FATF.pdf

Ashraf, M. M. (2020, February 08). Positive vibes from FATF meeting. The Nation. https://nation.com.pk/08-Feb-2020/positive-vibes-from-fatf-meeting

Basu, N. (2020). These are the parameters on which Pakistan has failed to meet FATF targets. The Print. https://theprint.in/diplomacy/these-are-the-parameters-on-which-pakistanhas-failed-to-meet-fatf-targets/369067/

Cooper, A. F., Heiner, J., \& Thakur, R. (2013). Introduction: the challenges of 21st-century diplomacy. In The Oxford handbook of modern diplomacy. Oxford University. https://www.oxfordhandbooks.com/view/10.1093/oxfordhb/9780199588862.001.00 01/oxfordhb-9780199588862-e-1.

Dawn News. (2020, January 25). Robust diplomatic efforts urged to get Pakistan off FATF grey list. https://www.dawn.com/news/1530362

DW News. (2019, July 17). Pakistan arrests alleged Mumbai attacks mastermind on terror charges. $\quad$ https://www.dw.com/en/pakistan-arrests-alleged-mumbai-attacksmastermind-on-terror-charges/a-49618392

DW News. (2019, October 18). Pakistan avoids FATF 'black list,' gets stern warning. https://www.dw.com/en/pakistan-avoids-fatf-black-list-gets-stern-warning/a$\underline{50870561}$

FATF. (n.d.). Who we are. http://www.fatf-gafi.org/about/

Felbab-Brown, V. (2018, February 5). Why Pakistan supports terrorist groups, and why the US finds it so hard to induce change. Brookings. https://www.brookings.edu/blog/order-from-chaos/2018/01/05/why-pakistansupports-terrorist-groups-and-why-the-us-finds-it-so-hard-to-induce-change/

George, u., \& Hussain, S. (2020, February 20). Pakistan hopes its steps to 'eradicate' terrorism will keep it off a global blacklist. The Washington Post. https://www.washingtonpost.com/world/asia_pacific/pakistan-fatf-terrorismblacklist/2020/02/20/df67602c-51e4-11ea-80ce-37a8d4266c09_story.html

Hussain, F. (2020, October 24). 'To remain on grey list': FATF urges Pakistan to complete action plan by Feb 2021. Dawn News. http://www.dawn.com/news/1586624

Idrees, M., \& Ayaz, M. (2015). Peace and conflicts in South Asia: A Case Study of Pakistan and India. International Journal of Political Science and Development, 3(10), 400404.

https://www.researchgate.net/deref/http\%3A\%2F\%2Fdx.doi.org\%2F10.14662\%2FI $\underline{\text { JPSD2015.048 }}$ 
Idrees, M., Rehman, A. U., \& Nazeer, M. (2019). Afghan Peace Process and the Role of Pakistan in Engaging the Stakeholders. Liberal Arts and Social Sciences International Journal (LASSIJ), 3(2), 20-34. https://doi.org/10.47264/idea.lassij/3.2.3

Jamal, U. (2019, July 31). Why Has Pakistan Set Up an FATF Cell at the Federal Bureau of Revenue? The Diplomat. https://thediplomat.com/2019/07/why-has-pakistan-set-upan-fatf-cell-at-the-federal-bureau-of-revenue/

Karim, S., \& Hayat, U. (2019). Pakistan on FATF's grey list: what, why, and why now? Dawn News. https://www.dawn.com/news/1418143

Khan, A. (2020, February 08). Financial Action Task Force (FATF). Modren Diplomacy. https://moderndiplomacy.eu/2020/02/08/financial-action-task-force-fatf/

McGlinchey, S. (2017, January 8). Diplomacy. E-International Relations. https://www.eir.info/2017/01/08/diplomacy/\#: :text=For\%20those\%20looking\%20for\%20a,objec tives\%20in\%20a\%20peaceful\%20manner.

Mohammad, N. (2019, October 5). Analysts: Pakistan Still at Risk of Being Placed on FATF Blacklist. VOA News. https://www.voanews.com/extremism-watch/analystspakistan-still-risk-being-placed-fatf-blacklist

Mukhtar, A. (2018). Money Laundering, Terror Financing and FATF: Implications for Pakistan. Journal of Current Affairs, 3(1), 27-56. https://ipripak.org/wpcontent/uploads/2018/10/Article-2-2-Oct-2018-ED-SSA.pdf

Noor, S. (2019, 11 21). Pakistan's political and diplomatic challenges at the 2020 FATF plenary. South Asian Voices. https://southasianvoices.org/pakistans-political-anddiplomatic-challenges-at-the-2020-fatf-plenary/

Saeed, F. (2019, October 10). Inconvenient Truth-FATF Diplomacy. Daily Times. https://dailytimes.com.pk/481660/inconvenient-truth-fatf-diplomacy/

Samuel, M. (2018, August 26). FATF Greylist: Any Way To Get Out!Moderndiplomacy. https://moderndiplomacy.eu/2018/08/26/fatf-greylist-any-way-to-get-out/

Shahzad, A. (2019, October 09). Pakistan expects to avert blacklisting over terrorism financing. Reuters. https://www.reuters.com/article/us-pakistan-terrorismfinancing/pakistan-expects-to-avert-blacklisting-over-terrorism-financingidUSKBN1WW2EG

Singh, H. (2020, February 17). What is the Grey List and Black List of the Financial Action Task Force? JagranJosh. https://www.jagranjosh.com/general-knowledge/grey-listand-black-list-of-the-financial-action-task-force-1551079247-

1\#: :text=Now\%20Grey\%20list\%20is\%20a,black\%20list\%20by\%20the\%20FATF.

Solaimankhail, M. (2020, October 21). Pakistan will remain in the faft grey list but thats not enough. The Diplomat. https://thediplomat.com/2020/10/pakistan-will-remain-inthe-fatf-grey-list-but-thats-not-enough/

Stanzel, V. (2018). New Realities in Foreign Affairs: Diplomacy in the 21st Century. German Institute for International and Security Affairs: Stiftung Wissenschaft und Politik. https://www.swp-berlin.org/en/publication/new-realities-in-foreign-affairsdiplomacy-in-the-21st-century/.

Syed, W. A. (2019, August 2). Improved Pak-US ties linked to irreversible action against terrorists. The News. https://www.thenews.com.pk/print/506917-improved-pak-usties-linked-to-irreversible-action-against-terrorists

The Wire. (2020, February 21). Explained: FATF, Pakistan and the 'Grey List'. https://thewire.in/diplomacy/fatf-pakistan-grey-list

The Economic Times. (2019, February 16). Financial Action Task Force to be given dossier to blacklist for fakistan terror links. 
https://economictimes.indiatimes.com/news/defence/financial-action-task-force-tobe-given-dossier-to-blacklist-pakistan-for-terror-

links/articleshow/68026309.cms?from $=\mathrm{mdr}$

Tripathi, R., \& Chaudhury, D. R. (2020, January 24). Pakistan to remain in FATF grey list, black listing looks unlikely. The Economic Times. https://economictimes.indiatimes.com/news/defence/pakistan-may-be-out-of-fatfgrey-list-next-month/articleshow/73562010.cms

TRT News. (2020, August 22). Pakistan sanctions Afghan Taliban to avoid FATF blacklisting. https://www.trtworld.com/asia/pakistan-sanctions-afghan-taliban-to-avoid-fatfblacklisting-

39112\#: :text=The $\% 20$ orders $\% 20$ were $\% 20$ issued $\% 20$ as,to\%20speak $\% 20$ to $\% 20$ the $\% 20$ media.

Wolf, S. O. (2019, October 21). COMMENT 155 - A Papyrus Victory: Pakistan's latest escape from the FATF's blacklist. https://www.sadf.eu/comment-155-a-papyrus-victorypakistans-latest-escape-from-the-fatfs-blacklist/

Xinhua. (2020, September 17). Roundup: Passage of FATF-related legislation to fortify Pakistan's economy. http://www.xinhuanet.com/english/2020$\underline{09 / 17 / \mathrm{c} \_139376923 . \mathrm{htm}}$ 